Gemma Pellissa Prades

\title{
The Italian sources of the Catalan translation of Ovid's Metamorphoses by Francesc Alegre (15th c.)
}

DOI 10.1515/zrp-2017-0022

Abstract: The singularity of Francesc Alegre's translation of Ovid's Metamorphoses into Catalan has been associated with its dependence on the Latin poem in contrast to the other versions of this text that circulated in print prior to 1500 . This article argues that the Catalan translation is the work of a learned author who places himself in relation to the Italian tradition and draws on different sources to complete a work influenced by humanist ideas. Moreover, the evidence strongly supports the impact of Giovanni Bonsignori's Ovidio Metamorphoseos Vulgare (c. 1375-1377) throughout the fifteen books of Alegre's translation and in his allegorical interpretations in the second part of the work. I also contend that he may have known the Expositio and the Allegorie written by Giovanni del Virgilio (1322-1323).

Keywords: Romance philology, comparative literature, vernacular translations, humanism, incunabula, the reception of Ovid, Catalan literature, medieval studies, Italian literature, mythology

\section{Introduction to Francesc Alegre's Transformacions}

The only medieval Catalan translation of Ovid's Metamorphoses that has been preserved to the present day was entitled Transformacions and was written in prose by Francesc Alegre between 1472 and 1482, approximately (Torró 1994). Later, it was revised in order to be published in Barcelona in 1494 with a print run of 1,000 copies (Hernando i Delgado 2002, 514-516). ${ }^{1}$

1 Approximately twenty copies of the text have been preserved (Torró 1994, 222).

Correspondence address: Dr. Gemma Pellissa Prades, Harvard University, Department of Classics, 204 Boylston Hall, Cambridge MA 02138, USA, E-Mail: gemmapellisa@gmail.com 
Nevertheless, Alegre mentions in his work's epilogue that Francesc Galceran de Pinós (ca. 1416-1475) had previously translated into Catalan some books from an Italian adaptation of Ovid's text (Giovanni Bonsignori's Ovidio Metamorphoseos Vulgare, ca. 1375-1377) and that another translator had undertaken the same task in Spanish. ${ }^{2}$ Pinós' translation into Catalan was lost and Alegre does not mention the authorship of the Spanish version. Similarly, he does not acknowledge Bonsignori's name in relation to the Italian compilation. Even so, Alcina (1998) proved through two examples from book I that Alegre knew Bonsignori's text, even if he based his translation, mainly, on Ovid's poem in Latin (Guthmüller 1997, 67 and 85). This assertion is core to the argument of this article, in which I will demonstrate the influence of Bonsignori throughout Alegre's translation, and also in his allegorical commentaries, in the second part of his work.

Thus, Alegre's Transformacions is an invaluable source for analyzing how Ovid's major work was received and interpreted in the Crown of Aragon in the late Middle Ages. Furthermore, this work begs further research questions regarding the circulation of Italian and French adaptations of the Metamorphoses in this geographical area. For example, in his epilogue, Alegre defends himself from critics by stating that, even if his work was not the first attempt to translate Ovid's text into a vernacular language, his project overtakes previous ones, as those (the Italian adaptation, Francesc Galceran de Pinós' and the Spanish one) depended on Giovanni del Virgilio's compilation in medieval Latin (1322-1323) - instead of having been translated directly from Ovid. ${ }^{3}$

It is certainly relevant that Alegre explicitly establishes a connection with these Italian works, but does not take into account the French tradition. As early as 1393, John I of Aragon wrote a letter to Henry of Bar, his brother-in-law, asking for a copy of "Ovidi methamorfoseos moralisat", a moralization of Ovid (Rubió i Lluch 1908-1921, 381, §CCCCXXVII). Cifuentes $(2006,183)$ explains that there may have been a Catalan translation of this work. Moreover, he argues that, although Rubió i Lluch identified the text requested by the king with the Ovide moralisé, it is more likely that he actually meant the Ovidius moralizatus by Pierre Bersuire (ca. 1342), as there was a Spanish translation of this work (Morales de Ovidio)

2 Regarding Francesc Galceran de Pinós’ translation, see Cabré/Ferrer 2011 (TCMP 10.1.1).

3 Surprisingly enough, Alegre does not acknowledge Arrigo Simintendi's translation of Ovid's Metamorphoses into Italian (fourteenth century), which solely depends on the Latin poem and had a rich transmission in manuscript form between the fourteenth and the fifteenth centuries, although it was not printed until 1852 (Ardissino 2001, xv). This text should be compared with the Catalan translation in full because it is closely related to the textual transmission of Bonsignori's text in Italy in manuscript form (Ardissino 2001, xxv-xxv, and Guadagnini 2016). In this article, I will argue that Alegre was influenced by Bonsignori's text. 
written before 1452 that seems to be based on a Catalan text (Riera i Sans 1989, 708). Therefore, Alegre's choice reflects the cultural changes regarding the translation of classical authors into Catalan in the fifteenth century. As Pujol (2004) points out, prior to that time, Catalan translators frequently used French works as go-between texts to access Latin authors. Regardless, after the beginning of the fifteenth century, the role of Italian literature should not be underestimated. Pujol calls attention to this fact through Francesc Galceran de Pinós' lost translation, as Alegre states that it drew on Bonsignori's text.

Examining the sources of Transformacions reveals more connections between Italian and Catalan literatures and it enables us to trace the transmission of those works and their impact in the Iberian peninsula. ${ }^{4}$ Alegre himself studied in Sicily with Giacomo Mirabella - who also taught Lucio Marineo Siculo - and he probably began a translation of Ovid's text as a grammar exercise while he was studying Latin under him. ${ }^{5}$ Moreover, although he probably returned to Barcelona during the Catalan civil war (1462-1472), he returned to Palermo in 1482 as a consul. ${ }^{6}$

In this article, I will identify the Italian sources of the Catalan translation of Ovid's Metamorphoses, whose first philological edition I am currently preparing. ${ }^{7}$ Despite the fact that Alegre's work includes a second part devoted to a euhemeristic interpretation of the myths based on Boccaccio's Genealogia deorum gentilium (Badia 1986) - the so-called "al-legories e morals exposicions” ('allegories and moral explanations') - I will focus on the translation.

Although Alegre wrote original works as well, he undertook the Catalan translation of Leonardo Bruni's De primo bello punico in 1472 through an Italian

4 Although the influence of Alegre's translation in Iberian literature has still to be determined, one of his original works, Faula de Neptuno i Diana ('Diana and Neptune's Fable'), contains parallelisms with Transformacions (Torró 1994, 234).

5 Torró (1994) presents the historical documentation regarding Giacomo Mirabella that has been preserved in the Arxiu de la Corona d'Aragó, which relates him with the prince Carlos de Viana, who was in Sicily between 1458 and 1459, and Ferdinand II of Aragon. In fact, Alegre dedicated his Transformacions to Ferdinand II's daughter, Joanna (cf. Marfany 2015 for new information regarding her). The above-mentioned Francesc Galceran de Pinós also belonged to Carlos de Viana's milieu, he participated in the literary exchange promoted by Pere Pou in 1458 (Deseiximents), penned a lament (Complanta) for the prince's death and, as Martí (1997) argues, he could have been the compiler of the manuscript Cançoner de Barberà, which, together with the Deseiximents, contains two poems composed by Carlos de Viana and three of Corella's texts in prose, among other pieces.

6 This summary regarding Alegre’s biography depends on Bescós Prat (2011, 4-24) and Torró (1994).

7 My edition is based on the incunabulum from the Biblioteca de Catalunya (Bon 10-VI-29), printed by Pere Miquel in Barcelona 24-VI-1494 (cf. Cabré/Ferrer 2011, TCM 92.3.1). 
version of the text (Badia 1986, 103). In the same way that Bruni coined the Latin term traducere to describe the act of translating as a way of substituting a cultural model for another one - differing from terms such as translatum -, Alegre used the neologism traduir with the same connotations in his work (Copeland 1991; Bescós Prat 2011). It is not about translating word by word (ad verbum) any more, nor about translating the sense of a text (ad sensum), as content and form are linked and the translation has to preserve what the original text said, as well as how it was expressed (Copeland 1991). In addition, in the epilogue of Transformacions, Alegre articulates a clear methodology regarding translation. He rejects ad verbum translations by stating:

\begin{abstract}
"No són molt luny de la condició dels dalt anomenats [folls], aquells qui dien que en lo trelladar se devia seguir la letra mot a mot, perquè no sol lo metre latí és quasi impossible posar en vulgar prosa, seguint-lo com està, mes la prosa imperfeta e fora de compàs se amostra tostemps que és seguida paraula per paraula. E los bons trelladors [...] han sol mirat en seguir les sentències, perquè la lengua latina e les vulgars distinctes, cascuna per sí en lo seu ydioma té son propi estil, que passat en altra llengua, acostuma offendre les orelles discrete" (Duran/Solervicens 1996, 40s.). ${ }^{8}$
\end{abstract}

The author also implies that his translation of the Metamorphoses offers an improvement in comparison with its predecessors due to the fact that the previous translators used Bonsignori's and Del Virgilio's works as go-between texts.

\title{
2 The Latin Source
}

Guthmüller (1997, 67 and 85) was the first scholar to underline the singularity of Alegre's Catalan translation because it was translated directly from Ovid, whereas the texts of the French and the Italian incunabula were not. ${ }^{9}$ Although it is not known which manuscript or edition of Ovid's Metamorphoses Alegre used in his translation, Bescós Prat $(2007,27$ s.) tries to shed light on this. As he explains,

8 "Those who say a translator should follow the text word by word [are fools], as it is almost impossible to translate Latin verses into vernacular prose without any change. As a result, the prose becomes imperfect and it lacks rhythm. The best translators [...] only work with entire sentences because, since Latin and vernacular languages are different, each language has a unique style, which, when one translates from one language into another, it bothers the subtle listener”. Except when otherwise indicated, all translations into English are my own.

9 Guthmüller (1998, 67 and 85) refers to the French version, printed in Bruges in 1484 (based on the Ovide moralisé and the Ovidius moralizatus, without any contact with the Latin poem) and Bonsignori's, printed in Venice in 1497. 
there are two different families that transmit the text, yet only one contains the fifteenth book. Therefore, if the Catalan translation showed no substantial differences between the rest of the books and the last one, it would probably mean that it had been based on the second family. In particular, Bescós Prat points to a manuscript similar to the French Parisinus 8001 and Parisinus 8000 - both of which were taken into account by Tarrant (2004), ${ }^{10}$ - considering that manuscripts generally spread across the Iberian peninsula through France. However, the scholar compared these texts with the first book of Transformacions without achieving relevant results.

Furthermore, Moncunill Martí $(2005,147)$ argues that the codices recentiores of Ovid's text must be considered in order to find Alegre's source, as they are normally not collected in critical apparatus. Additionally, she proves through four examples how some excerpts from the Catalan translation differing from Ovid show striking similarities with these late manuscripts in Latin. Alternatively, it is also true that Giovanni del Virgilio's text, together with Bonsignori's and the Ovide moralisé may also account for these differences. ${ }^{11}$ She concludes:

"Podemos otra vez plantearnos si estas traducciones están, todas ellas, más imbricadas de lo que creíamos o si, por lo contrario, la confluencia se debe simplemente a la difusión de un modelo textual común de las Metamorfosis sobre el cual surgirían las adaptaciones medievales” (Moncunill Martí 2015, 149). ${ }^{12}$

In addition, Moncunill Martí clarifies that, even if the six incunabula containing Ovid's text have only been partially collated, they should also be taken into account, as Alegre could have known them. Despite this, she considers that certain lectiones from the Catalan translation would be difficult to explain if based on an incunabulum. The editions that preceded the printing of Alegre's text are the following: Puteol. 1471, Aler. 1471 (based on the fifteenth-century manuscript Vaticanus Chisiamus H.V.164), Venet. 1472, Calph. 1474 (based on Parisimus Lat. 8016, 1401-1501, which was part of the Library of the Aragonese Kings of Naples), Accurs. 1475, Calder. 1477 (which is the same as Accurs. 1475, with corrections and a Vita Ovidii) and Regius 1493 (widely distributed, although the date of the

10 For the full stemma, see Tarrant (2004, xxvii).

11 There is currently a research project devoted to the Ovide moralisé that might shed light on the topic highlighted by Moncunill: Project OEF, "Ovid in French. Genesis, transformation and reception of Ovide moralisé”, coordinated by Marylène Possamai-Perez since 2013.

12 "We must consider whether these translations are more closely related between them than we first thought or, on the contrary, if they converge because they had a textual prototype of the Metamorphoses in common. After this model, the medieval adaptations of the text might have been undertaken". 
edition makes it an improbable choice). ${ }^{13}$ Martí Duran, a collaborator of my edition project, has compared some selected passages from Alegre's translation with the above-mentioned editions following the advice of Luis Rivero García, but, to date, there has not been a match.

Regarding the manuscripts containing the Metamorphoses, Duran has compared the Catalan translation (the entire books I-XI) with the texts collated by Tarrant (2004). According to his stemma (27), Alegre follows either the lectiones of the branch of the manuscripts Marcianus Florentinus 225, Neapolitanus Bibl Nat. IV. F. 3 and Vaticanus Vrbinas lat. 341, or the ones of the branch to which Vaticanus Pal. lat. 1669 belongs. Duran also took into account some selected excerpts from the manuscript Dertusensis MS. 134 Arch. Capit., preserved in Tortosa, because of its geographical proximity with Alegre's text, but, likewise, it was not a match. In summary, as Moncunill Martí (2015) suggested, the manuscript from which Alegre translated the text was probably a late manuscript of Ovid with evident signs of contaminatio.

Since the Catalan text's main source is not a compilation or a synthesis of Ovid's work, but, rather, the Latin text of the Metamorphoses, it contains details that are not in works such as Bonsignori's adaptation. ${ }^{14}$ Furthermore, Alegre's version includes mistakes that can be explained by his dependence on a Latin text. For example, “comas Helicen” (Tarrant 2004, V, v. 87) ('Unshorn Helices', Lombardo 2010, 124, v. 103) was translated as “comas Elicen”, although comas does not exist in Catalan. It is also remarkable that, unlike Del Virgilio and Bonsignori, Alegre's translation does not contain lengthy digressions from Ovid's story.

13 Moncunill Martí $(2015,148)$ already mentions the six incunabula that should be taken into account. The list reported in this article depends on the inventories of manuscripts and editions of Ovid's Metamorphoses made by the Nicolaus Heinsius research group (Bellido et al. 2014). I am thankful to Luis Rivero Garcia, who has offered us valuable information regarding these texts.

14 This does not mean that Alegre always followed Ovid's text closer than Bonsignori. In certain occasions, Alegre summarizes some details that Bonsignori reports in his work. For instance, regarding Ovid (VIII, vv. 372-375), Bonsignori writes: "Ma intanto sopravenne Castor e Polluce su doi cavalli bianchi" (Ardissino 2001, 397) ('But, in the meanwhile, Castor and Pollux turned up on their white horses') whereas Alegre does not mention the animals: "E mirant tal estral, Càstor $\mathrm{y}$ Pòluix venguéran per a ferir-lo”, f. 68vo[67voㅡ ("And, staring at the damage, Castor and Pollux came to hurt the beast'). In fact, there are procedures that Alegre applies: 1 . he tends to simplify Ovid's similes; 2 . shortens lists of proper names and avoids syntactic repetitions; 3 . uses direct or reported speech independently of Ovid; 4. introduces slightly moral connotations; 5 . reduces erotic comments and references to homosexuality; 6 . ambiguity recedes in his version; 7 . he amplifies sentimental passages; 8 . in the beginning of a new chapter, he adds sentences to recap; 9. explains terms referring to the classical world, popularizes periphrasis or proper names and, in other occasions, transforms Latin references into their medieval equivalents. 


\section{Italian Sources}

Despite Alegre criticizing the previous translations into Catalan and Spanish for drawing on the Italian adaptation of Ovid's poem by Giovanni Bonsignori, ${ }^{15}$ Martí de Riquer $(1934,8)$ already suspected that he might have turned to this compilation as a secondary source to undertake his own translation. Nevertheless, it was not until 1998 that Alcina verified this hypothesis with two examples from book I. Until now, however, the Catalan translation had not been fully compared to Bonsignori's text.

Bonsignori's work combines the expositio of the Metamorphoses with the allegory of the myths in the same text. At the end of the first book, Bonsignori stops translating directly from Ovid and starts using the Latin adaptations of Ovid's work by Giovanni del Virgilio, who penned the Expositio and the Allegorie circa 1322-1323 (Ardissino 2001, xIII). ${ }^{16}$ Both works are independent from each other, the former being an educational text, that is, an exposition of the poem for grammar students, while the latter, composed with further ambitions, offers a commentary based on the allegories written by Arnulf of Orléans, John of Garland and the Vulgate Commentary, alternating prose and verse for mnemonic purposes (cf. Ghisalberti 1933, 34-39; Ferretti 2007; Clark/Coulson/McKinley 2011). Bonsignori uses both texts in his compilation (Ardissino 2001, XIII). ${ }^{17}$

15 In relation to Giovanni del Virgilio's adaptation of the Metamorphoses, which is the main source of Bonsignori's text, Alegre affirms in his epilogue: "és tal traductió composta de espines, dexant la multitut de odoríferes flors ab què lo nostre poeta ornà lo seu escriure, ajustant lo dit toscà ab les faules de Ovidi, trocejades moltes al-legories segons la fantasia. De aquest latí gros fon tret lo que és en toscà" (Duran/Solervicens 1996, 40) ('This translation contains thorns and dismisses the many fragrant flowers with which our poet [Ovid] embellished his writings. The Tuscan compiler added to Ovid's fables, fragmented, a large number of allegories created by his imagination. From this vulgar Latin he translated the Tuscan text').

16 As Ferretti (2007) notes, in his allegories, Bonsignori just draws on the part of the Allegorie that Del Virgilio wrote in prose. The scholar also argues that the parts that Del Virgilio composed in verse were more likely to be written down in the margins of manuscripts.

17 Bonsignori progressively reduces the use of Ovid's text throughout book I and he finally turns to Del Virgilio's adaptations as his main sources at the end of this book (Ardissino 2001, 131 and 144). From this point on, Ardissino writes in the notes the differences between both texts. There are currently two projects devoted to the edition of Del Virgilio's works. Huber-Rebenich and Beatrice Wyss are preparing the edition of his Expositio and Cotza is working on the Allegorie, as Ghisalberti's edition (1993) was not a philological one (Ferretti 2007). Moreover, Ferretti explains that the version of this text translated into Italian by Bonsignori (and also that translated in Florence at the end of the fourteenth century by an unknown author) is still unpublished. The scholar also remarks that a study of the Allegorie's manuscript tradition through marginal glosses is still needed. 
Indeed, Ardissino outlines that Bonsignori's original contributions to the work are, essentially, his preface (Proemio) and his exordium (Essordio), most of the first book as well as some punctuated additions throughout the text. In turn, Guthmüller $(1997,89)$ argued that Alegre knew Bonsignori’s preface and Bescós Prat (2014, 47s.) proved that he borrowed the etymological explanation regarding the title of Ovid's work, Metamorphoses, from either Bonsignori or Del Virgilio. However, the similarities between the four reasons that Bonsignori states for writing his work in the prologue and the three purposes Alegre mentions for his translation are vague. Although one could compare Bonsignori's second aim to Alegre's one, the parallelisms are far from clear: "el secundo sta nei libri de' notarii e dei mercatanti, li quali fanno memoria de le cose che le gente convengono insieme" (Ardissino 2001, 4). ${ }^{18}$ According to Alegre: "la segona utilitat serà aclarir lo entendre e hedificar la memòria", f. $2 \mathrm{r}^{\mathrm{0}}{ }^{19}$ Moreover, the third reason Alegre develops in his text - guiding the readers' lives by means of exempla, as Ovid would prove through many metamorphoses how good people are rewarded and the bad end up being punished - is often used in the accessus that precede the medieval translations of Ovid's Heroides too (Pujol 2002).

On the contrary, Alcina's examples $(1998,41)$ clearly show Alegre's dependence on Bonsignori's text in book I, in which Bonsignori does not entirely depend on Del Virgilio:

\section{Example 1}

- "rudis indigestaque moles" (Tarrant 2004, I, v. 7)..$^{20}$

- "E fu una grossa e non compartita composizione" (Ardissino 2001, 101). ${ }^{21}$

- "E era una grossa e no compartida composició" (Alegre, f. 1r으마의]).

\section{Example 2}

- "nullus adhuc mundo praebebat lumina Titan, / nec noua crescendo reparabat cornua Phoebe" (Tarrant 2004, I, vv. 10-11). ${ }^{23}$

18 'The second reason is already in the books of notaries and merchants, who preserve in memory what people have agreed upon'.

19 'The second function is to improve our understanding and to strengthen memory'. I have italicized and underlined certain parts of the examples to highlight particular elements of the text supporting my argumentation.

20 "A crude, unsorted mass" (Lombardo 2010, 5, v. 7).

21 'It was a big and undivided conglomeration'.

22 'It was a big and undivided conglomeration'.

23 "No Titan Sun as yet gave light to the world, / No Phoebe touched up her crescent horns by night” (Lombardo 2010, 5, vv. 10-11). 
- "E niuno sole o luce rendea lumen el mondo, né la luna crescendo rempiva le sue corna" (Ardissino 2001, 102). ${ }^{24}$

- "Negun sol retia lum al món ne la luna crexent reomplia los novells corns" (Alegre, f. $\left.1 \mathrm{r}^{\mathrm{o}}[\mathrm{3r} \mathrm{r}]\right) .{ }^{25}$

In this article, I will argue that Alegre uses the Italian source consistently throughout the fifteen books and even in his "al-legories e morals explicacions". Nonetheless, as I mentioned before, we have to bear in mind that, after book I, Bonsignori follows Giovanni del Virgilio. Therefore, as Bescós Prat (2014, 46) points out, "un primer pas és tenir clar què hi ha de Del Virgilio en el text de Bonsignori abans d'establir una relació Alegre-Bonsignori que en realitat podria remuntar-se a Alegre-Del Virgilio". ${ }^{26}$ In fact, despite not mentioning Bonsignori by name, Alegre does explicitly refer to Del Virgilio, even if the Italian manuscripts from the fourteenth century that have transmitted Bonsignori's work do not report the authorship of the Latin adaptation (Guthmüller 1997, 88). However, the Catalan translator states that Giovanni del Virgilio - instead of Bonsignori - is responsible for having mixed the expositio and the allegories (Bescós Prat 2014, 46), which does not reflect a deep knowledge of his corpus.

Yet, Bescós Prat (ib., 49s.) defends that, at the beginning of the first book, in which Bonsignori still does not depend on Del Virgilio, there are no parallelisms between Alegre and the Italian text. He exemplifies his thesis with some passages from this book. Paradoxically, one of them is the same as the second example used by Alcina to prove the contrary. Bescós Prat notes that Alegre translated Ovid's "noua" into "novells" ('new'), while the Italian version does not contain an equivalent for this term. Needless to say that this example fits in with the hypothesis that Alegre uses Bonsignori as an aid while translating from Ovid, not as his main source, but in a consistent way.

24 'There was no sun or light giving light to the world, no crescent moon filled her horns up'.

25 'There was no sun giving light to the world, no crescent moon filled her new horns up'. Elisa Guadagnini suggested to me that the Catalan translation reads, in the passage regarding Alcina's second example, in the same way as Simintendi's translation into Italian: "Niuno sole dava ancora lume al mondo; e la luna non riparava i nuovi corni crescendo" (Guasti 1846, 4) ('There was no sun giving light to the world, no crescent moon filled her new horns up'). On the contrary, Alcina's first example is translated in the following way by Simintendi: "era rozza e non divisa gravezza" (Guasti 1846, 4) ('It was a rough and undivided heaviness').

26 'As a first step, it is essential to clarify what comes from Del Virgilio in Bonsignori's text before establishing a link between Alegre and Bonsignori that could actually go back to Del Virgilio's work'. 


\section{Thesis and methodology}

In this article I will argue the following thesis:

a) Even if Alegre's main source is Ovid's poem in Latin (probably, a codex recentior), the dependence between Alegre and Bonsignori - used as a secondary source - can be proved throughout the fifteen books.

I will confirm this statement with at least one example from each one of the books. This is not an exhaustive list, although one may find it in my edition, which I employ here for Alegre's quotes. Regarding Bonsignori's text, I have compared the entire Catalan translation with Ardissino's edition (2001), which is based on the manuscript tradition of the Italian text. Even though the scholar explains that the work did not circulate largely before print, the first edition dates from 1497; therefore, Alegre must have known a manuscript form, as did Francesc Galceran de Pinós some years before. It is likely that the milieu of the prince Carlos de Viana, to which Pinós and Giacomo Mirabella belonged, had access to the text in the late fourteen fifties. The Spanish version of the work could have been produced in the same court. Although Bonsignori's transmission is often closely linked with the Italian translation of the Metamorphoses by Simintendi, ${ }^{27}$ Alegre seems to have had access to a manuscript containing Bonsignori's whole work, as he shows its influence throughout the fifteen books. This point has to be considered to recognize the branch of the Italian work that Alegre used.

b) In some cases in which Bonsignori differs from Del Virgilio, Alegre still shows traces of the Italian text. I use Ardissino's notes to the Italian version in order to identify any differences that arise between Bonsignori and Del Virgilio and to examine if Alegre imitates one of these solutions. ${ }^{28}$ In addition, I have also checked Ghisalberti's edition (1933) of his Allegorie and Beatrice Wyss and Ger-

27 For more on Bonsignori's textual transmission, see Guadagnini (2016). Among the nine manuscripts that have transmitted Bonsignori's text, four of them contain Simintendi's translation together with Bonsignori's allegories. The only manuscripts that have preserved the integrity of Bonsignori's text are New Haven, Beinecke Rare Book and Manuscript Library, Yale University, Ms 688 (and its descriptus), Città del Vaticano, Biblioteca Apostolica Vaticana, Urbinate Latino 644 and, except for the Proemio and a part of the Essordio, Firenze, Biblioteca Nazionale Centrale, Palatino 466. Ardissino's edition (2001) is based on the latter manuscript. Simintendi's translation had a successful transmission in manuscript form in the fourteenth and the fifteenth centuries (Ardissino 2011, xv).

28 Ardissino (2001) transcribes some excerpts from Del Virgilio's Expositio through the manuscript New York, Pierpont Morgan Library, MS. 938. Unless otherwise noted, I quote her transcriptions of Del Virgilio's text. 
linde Huber-Rebenich have provided me with some materials from Del Virgilio's Expositio (examples 9 and 18).

Either Alegre consciously decides not to cite Bonsignori as an auctoritas in his epilogue, or the manuscript containing the Ovidio Metamorphoseos Vulgare he had access to did not report his name.

c) On a few occasions in which Bonsignori diverges from Del Virgilio, Alegre may follow the later. There are signs that Alegre could have known both the Expositio and the Allegorie written by Del Virgilio. ${ }^{29}$

Therefore, even if none of the known manuscripts that transmit Del Virgilio also includes Bonsignori, Alegre seems to know the works of both compilers. Perhaps his manuscript of Bonsignori's text contained Del Virgilio's lectiones in the margins and it mentioned the name of the compiler in Latin. Another possibility is that the manuscript of Bonsignori used by Alegre reported some lectiones that differ from the text edited by Ardissino (2001). These lectiones might be closer to Del Virgilio, but it would not necessarily mean that Alegre also knew the Expositio and the Allegorie directly. In fact, according to Ardissino, there are two stages in the composition of Bonsignori's text, both of them controlled by the author. She edits $P$ (Firenze, Biblioteca Nazionale Centrale, Palatino 466), which belongs to the second stage of the textual transmission of the work - together with its first printed edition - and reports all the variations of this branch. Moreover, in a second apparatus, she gathers the different lectiones from the first stage, but she does not include the ones that have been preserved in only one manuscript. Finally, Ardissino (2001, xxxiv) mentions the probable existence of lost manuscripts of this work. ${ }^{30}$

29 There are seven manuscripts containing the complete text of the Expositio, as Huber-Rebenich has noted (Guthmüller 1997, 65). The Allegorie have been transmitted by twenty-seven manuscripts in its original form and ten manuscripts report some of its passages in the margins of Ovid's text (Ghisalberti 1933, 7s. and Ferretti 2007). The Catalan translator is convinced that both texts were part of the same work, and probably mixed. Even if there is no evidence that they were combined, Ferretti (2007) explains that Giovanni Ippoliti da Mantova, an instructor of Latin in Brescia in the fourteenth century, transcribed Del Virgilio's paraphrase and his commentary together with other texts related to Ovid in the manuscript Milano, Biblioteca Nazionale Braidense, AF XIV 21. He lists other manuscripts that contain both works. Ferretti (2007) argues that the Allegorie circulated in private schools, in universities and in court libraries. This work and the Expositio were found in important humanistic libraries.

30 For the full stemma, see Ardissino (2001, lxix). 
The following diagram illustrates these connections:

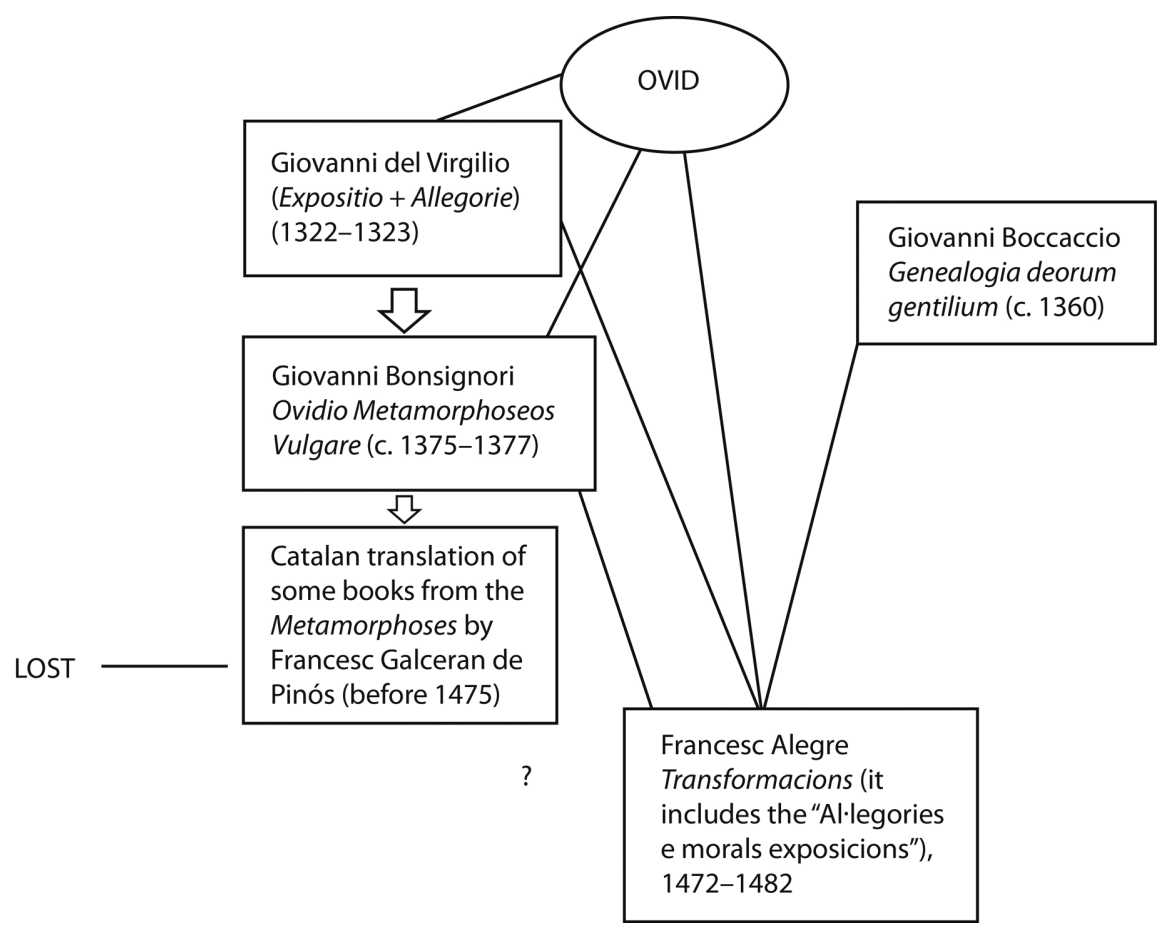

\section{Parallelisms between Alegre-Bonsignori}

In this section, I will prove by means of examples from book I to book XV that Alegre turns to Bonsignori's text as an aid for his translation into Catalan of Ovid's Metamorphoses. Bear in mind that Alegre is as subtle a translator as he is as an original writer in his sentimental romances. On the one hand, he uses literal passages from the Italian text, but these are not easy to identify, as Alegre does not borrow long excerpts and, sometimes, it is difficult to know if both translators came up with the same solution solely based on Ovid. On the other hand, he adds brief glosses or details that bring new information to the Latin poem.

\section{EXAmple 1 (воOK I)}

The following case exemplifies the first technique in book I, in which Bonsignori is still not translating from Del Virgilio. The examples showed by Alcina $(1998,41)$ also fell into this category. 
- "principio terram, ne non aequalis ab omni / parte foret, magni speciem glomerauit in orbis” (Tarrant 2004, I, vv. 34-35). ${ }^{31}$

- "adunò la terra in grande rotondità, acciò ch'ella fosse da onne parte eguale, sì che non grevitasse da una parte più che dall'altra" (Ardissino 2001, 102)..$^{32}$

- "primer, ajustant la terra, li donà forma rodona perquè egual a totes parts se mostràs $e$ d'una part no pesàs més que d'altre" (Alegre, f. $\left.1 \mathrm{r}^{\mathrm{o}}\left[3 \mathrm{r}^{\mathrm{o}}\right]\right)$. $^{33}$

The parallelisms between Alegre and Bonsignori are clear, although it is even more evident that the Catalan translation is influenced by the Italian version when the differences between the former text and Ovid are explained by a modification or an addition transmitted through Bonsignori.

\section{EXAMPLE 2}

- "positoque tricuspide telo / mulcet aquas rector pelagi, supraque profundum / exstantem atque umeros innato murice tectum [...]” (Tarrant 2004, I, vv. 330-333). ${ }^{34}$

- "Allora Nettuno puse giù la sua bachetta e chiamò el suo trombetino chiamato Tritone, el qual estava sopra l'acqua ed avea coperte le spalle de verde lima<cci>a d'acqua" (Ardissino 2001, 116). ${ }^{35}$

- "Neptuno, posada la trident verga, cridà Triton, son trompeta, al qual de la aygua exint ab les espatles verdes" (Alegre, f. 6ำ). ${ }^{36}$

In this example, the italicized parts of the excerpts show how the differences between Alegre's translation and his main source, Ovid, already existed in Bonsignori's text. The Italian compiler added a brief gloss to introduce a new character to his readers, Triton, and he changed the color of the shellfish covering his shoulders. Alegre includes the explanation given by Bonsignori and also the detail of the color. Nevertheless, he is more faithful to Ovid than the Italian text because he depicts Triton going out of the water - Alegre uses a gerund to describe this action, - whereas, in Bonsignori's text, he is already above the sea.

31 "Then the denser earth attracted the heavier elements / And was pushed down by her own weight” (Lombardo 2010, 5, vv. 29-30, “The Four Ages”).

32 '[The god] gathered the earth in a round form to make it equal from every angle in order to avoid that one half would weigh more than the other half.

33 'Firstly, [the god] gathered the earth and gave it a round form to make it look equal from every angle and to avoid that one half would weigh more than the other half.

34 "He hailed / Cerulean Triton rising over the crests, / His shoulders encrusted with purple shellfish" (Lombardo 2010, 15, vv. 344-346, "Deucalion and Pirra”).

35 'Then, Neptune put his trident down and called his trumpeter, named Triton, who was above the water and had his shoulders covered with green shellfish'.

36 'After he put his trident down, Neptune called Triton, his trumpeter, who went out of the water with his shoulders looking green’. 


\section{EXAMple 3 (воOK II)}

- "ecce uenit rutilis umeros protecta capillis / filia Centauri, quam quondam nympha Chariclo / fluminis in rapidi ripis enixa uocauit / Ocyroen” (Tarrant 2004, II, vv. 635638)..$^{37}$

- "Ex quadam ninpha Cayci fluminis nomine Carito" (Giovanni del Virgilio 20ro, Ardissino 2001, 182). ${ }^{38}$

- "Questo Chiron avea una sua figliuola chiamata Chiride, la quale avea auta d'una ninfa chiamata Caia, dea del fume chiamato Chiciton; questa Ochiride [...]”(Ardissino 2001, 165s.). ${ }^{39}$

- "Tenia aquest una filla, e lo nom d'ella Achiroe, la qual en temps passat havia haguda en les corrents ribes de Chariton de la gentil e delicada nimfa Chayo" (Alegre, f. 16ro[ [19ro이..$^{40}$

This episode deals with the daughter of the centaur Chiron, who was a seer. She is introduced here through her genealogical information. In Ovid's text, Ocyrhöe is the daughter of the nymph Chariclo and the centaur. The second passage has been taken from Del Virgilio, because, as has been explained, Bonsignori translates from this text after book one. If there are no differences between the Italian version and Del Virgilio's adaptation, I will not mention it, because it would be impossible to know if Alegre would have known one version or the other. Nevertheless, on this occasion, Alegre follows Bonsignori even if the Italian text differs from Del Virgilio. Here, Del Virgilio maintains the name of the nymph and he adds a new proper name (Cayci) to refer to the river, which was unnamed in Ovid - I have underlined the places in which the river receives a name. In the Italian text, "Cayci" no longer refers to the river, but to the nymph (Caia). Likewise, Alegre uses this name (under the form of "Chayo") to talk about the nymph. Bonsignori probably read in Del Virgilio's text "nimpha Cayci” together, instead of "Cayci fluminis" and he thought that "Carito" was associated with the river ("fluminis nomine Carito"). However, in Ovid, this was the original name of the nymph: Chariclo.

To sum up, both Bonsignori and Alegre exchange the names of the nymph and the river. The only name that does not differ from Ovid is the one that refers to the centaur's daughter.

37 "Comes running, red-gold hair flowing and tumbling / Over her shoulders. The nymph Chariclo bore her / On the flanks of a swifty flowing river, and ever after / Called her Ocyrhöe” (Lombardo 2010, 53, vv. 713-715, “Ocyrhoë”).

38 'From a certain nymph from the river Cayci, named Carito'.

39 'Chiron had a daughter named [O]Chiride, who had been given birth by a nymph called Caia, goddess of the river Chiciton; this Ochiride [...]'.

40 'He had a daughter called Achiroe, whom the delicate and pleasant nymph Chayo had given birth to on the banks of the swiftly flowing river Chariton'. 


\section{EXAMPle 4 (воOK III)}

- "Ecce cruentati redeunt et Bacchus ubi esset, / quaerenti domino Bacchum uidisse negarunt; / 'hunc' dixere 'tamen comitem famulumque sacrorum / cepimus' et tradunt, manibus post terga ligatis / [sacra dei quondam Tyrrhena gente secutum]” (Tarrant 2004, III, vv. 572-576). ${ }^{41}$

- "Al comandamento de Penteo andarono li figliuoli de lui per trovare Baco, ed andando trovaro altro che uno vecchio, el quale egli menaro ligato denanti a Penteo" (Ardissino 2001, 203).42

- "per on cuytàs sos servidós anaren per a pendre a Bacho e, no trobant sinó un vell cansat,

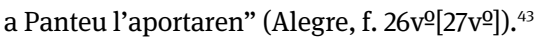

Apart from the fact that they mention finding an old man instead of a follower of Bacchus, the way this story is narrated in Alegre is very akin to Bonsignori's text. However, the Catalan text does not contain the information about the prisoner being tied up, which was already in Ovid and is also transmitted by Bonsignori. In the episodes in which an evident parallelism between Alegre and Bonsignori is found, it is feasible to identify many other similarities, as it is the case of Bacchus' passage.

\section{EXAMPLE 5 (воOK IV)}

- "celebrant lucemque perosae / nocte uolant seroque tenent a uespere nomen" (Tarrant 2004, IV, vv. 414-415) ${ }^{44}$.

- “[...] mutate sunt in vespertiliones” (Del Virgilio, 35rº, Ardissino 2001, 258). ${ }^{45}$ Del Virgilio does not keep the riddle, but he directly says the creature's name.

- "le dio Baco le mutò in vespertilli, cioè in nottule [...]. E né mai per questa cagione se lassano vedere de dì, ma solo vanno depo vespero, e perciò sono nominate vespertilione per lo vespero" (Ardissino 2001, 230). ${ }^{46}$

41 "Now the guards are back, covered with blood / And explaining that they never saw Bacchus, / But, 'We got one of his devotees', they said, / And handed him over, hands bound behind him, / An Etruscan and follower of the god's sacred rites" (Lombardo 2010, 83, vv. 631-535, "Pentheus and Bacus").

42 'Following Pentheus' orders, his sons sought for Bacchus, but they only found an elderly man, whom they bound and led to Pentheus'.

43 'He rushed his servants to seek for Bacchus and get him, but they only found a tired, elderly man, whom they led to Pentheus'.

44 "And hating / The light of the sun they flit about in the evening, / Twilight creatures that are called vesper bats" (Lombardo 2010, 104, vv. 452-454, "The Daughters of Minyas Become Bats").

45 'They were transformed into bats'.

46 'The god Bacchus transformed them into vespertilio, that is to say, bats [...]. And this is the reason why they never go out during the day, but they do after dusk; because of that, they are called vespertilio - after the evening'. 
- "Y, vòlan en la nit, da on han pres lo nom, y de exir la vesprada són dits vespertilions y, segons alguns volen, foren aquestes en mosquits convertides, perquè vespertilió és nom comú a tots aquells aucells que volen en la nit” (Alegre f. $36 \mathrm{v}-\left[38 \mathrm{v}\right.$ ㅇ]). ${ }^{47}$

In this example, the translators into vernacular languages face a challenge because Ovid is playing with the etymology of the Latin word vespertilione, whereas the equivalent term in Italian is pipistrello or nottola and, in Catalan, ratpenat, ratapinyada or ratapenada, which have nothing to do with vesper ('night'). By describing the behavior of bats and explaining that they are named after vesper ('night'), Ovid's readers understand that he is referring to bats, but the Italian and the Catalan ones cannot infer it from the root of the word. This is the reason why Bonsignori and Alegre maintain the Latin term as a neologism in the vernacular languages ("vespertilli" and "vespertilione" in the Italian version and "vespertilions" in the Catalan one). In Catalan, the historical dictionary Diccionari català-valencià-balear reports this word, but the only example provided is the one from Alegre's translation. Both Bonsignori and Alegre choose to use a neologism because it allows them to link the meaning with vespere as Ovid did, since vespero/vespro and vesprada ('evening') are common names in these languages. However, they need to offer a translation of this word in their languages, which is why Bonsignori adds 'that is to say, bats' ('nottule'). Surprisingly enough, Alegre translates it as 'mosquitos'. The Catalan author might have turned to Bonsignori for aid in this difficult passage.

\section{EXAMPLE 6 (воOК v)}

- "fele soror Phoebi” (Tarrant 2004, V, v. 330).48

- "Sed domina Diana ibi latuit in cervia et ideo est sibi dedicata ut vos dicitis" (Del Virgilio, 44ró; Ardissino 2001, 289).49

- "Diana se mutò in cervia e perciò è consacrata a llei la cervia" (Ardissino 2001, 269).50

- "Diana se convertí en una gentil sírvia" (Alegre f. 44ro[42ro ] ]). ${ }^{51}$

47 'They fly at night and they are called bats ['vespertilions'] because of that. Plus, according to some people, they were transformed into mosquitos, since vespertilio is the word used with all of the birds that fly at night'.

48 "Diana [hid in the shape of] a cat" (Lombardo 2010, 132, v. 385, "The Contest of the Muses").

49 'But lady Diana hid in the shape of $a$ doe and this is the reason why this animal is consecrated to her'.

50 'Diana transformed herself into $a$ doe and this is why the doe is consecrated to her'.

51 'Diana transformed herself into a graceful doe'. 
Even if Alegre's solution to this passage could have come from either Del Virgilio or Bonsignori, he follows the same structure as the Italian text. ${ }^{22}$ It is also worth mentioning that in the preceding verse, Ovid had described the following transformation: "Delius in coruo" (Tarrant 2004, V, 329) but some manuscripts report “cervo" instead of "coruo" (ib.). ${ }^{53}$

\section{EXAMPLE 7 (воOK vi)}

In the following example, Alegre shows he has a good knowledge of Bonsignori's text. ${ }^{54}$

- "fecit et Asterien aquila luctante teneri” (Tarrant 2004, VI, v. 108). ${ }^{55}$

This metamorphose is listed in Ovid between the rape of Europe and Leda lying with an apparent swan, but, as Ardissino (2001, 330) observes, Bonsignori does not report the transformation of Jupiter into an eagle at this point of the account (ib., 299). Yet, the Italian translator includes this myth as the last one portrayed by Arachne (ib., 301) and he maintains this order in his allegorical commentary. Nevertheless, Bonsignori changes the name of the victim, unlike Del Virgilio (ib., 330). Alegre will do the same, even if he maintains the same order as Ovid:

- "E depinse ne l'ultimo come Giove, mutato in aquila, rapìo Ganimede" (Ardissino 2001, 301). ${ }^{56}$

- "Brodà a Júpiter com convertit en àguila furtà a Ganimedes" (Alegre f. 48vo[47vo] ]). 57

\section{EXAMPLe 8 (воOK ViI)}

- "bella parat Minos; qui quamquam milite, quamquam / classe ualet, patria tamen est firmissimus ira / Androgeique necem iustis ulciscitur armis" (Tarrant 2004, VII, vv. 456458)..$^{58}$

52 It should also be compared with other medieval versions of the Metamorphoses to see whether this is a common interpretation of the text during the Middle Ages, as Diana is the goddess of the hunt. In fact, the Ovide moralisé (Boer 1915, V, 1828) reports the same transformation: "Et Diana en biche sauvage" ('And Diana into a wild doe').

53 "Apollo hid in the shape of a crow" (Lombardo 2010, 132, v. 384, "The Contest of the Muses").

54 On other occasions, the information he includes in the Catalan translation, belongs to Del Virgilio's or to Bonsignori's allegories, not to his paraphrase.

55 "She made Asterië struggling in the eagle’s claws" (Lombardo 2010, 150, v. 119, “The Contest of Arachne and Minerva”).

56 'In the last place, she depicted how Jupiter, transformed into an eagle, raped Ganymede'.

57 'She embroidered how Jupiter was transformed into an eagle and kidnapped Ganymede'.

58 "Minos was planning a war. / He was strong in ships and men, but his greatest strength / Was his anger as a father, and he meant to avenge / The death of Androgeous with a righteous war" (Lombardo 2010, 189, vv. 507-510, “Minos’ Embassy to Aegina”). 
- "cum Androgeus filius regius Minos cretensis in Athenis occisus fuisset per invidiam [...]" (Del Virgilio, 62vo , Ardissino 2001, 377). ${ }^{59}$

- "Androgeo, figliuolo del re Minoi de l'isola de Creti, fu morto ad Atene dagli scolari per invidia, perciò ch'egli imparava oltra gli soi compagni”" (Ardissino 2001, 360)..$^{60}$

- "que lo rey Minos decret per a venjar la mort de Andrògeo, fill seu, mort en Atenes mentre estudiava. Contra aquella ciutat aparellava guerra” (Alegre f. 60v의 [59vo $]$ ). ${ }^{61}$

In this episode, Del Virgilio adds some details to Ovid's text, Bonsignori keeps the information and completes it and Alegre includes all the previous details apart from the fact that envy was the cause of murder. The lack of this particular detail may indicate that Alegre could have drawn on some glosses accompanying Ovid's manuscript as well. Therefore, we cannot dismiss another source for this particular example, as medieval translators usually turned to these types of glosses. The Vulgate Commentary contains the same information; it mentions envy as the cause of murder and it even explains that the boy was pushed from a tower. ${ }^{62}$ In spite of this fact, Alegre identifies envy as the reason for his dead in the allegory of the myth in folio $198 \mathrm{r}^{\mathrm{O}}[184 \mathrm{r}$ ㅇ].

\section{EXAMPLE 9 (воOK VIII)}

- "splendidus ostro" (Tarrant 2004, VIII, v. 8).63

- "d'oro" (Ardissino 2001, 381)..$^{64}$

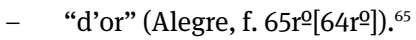

This example belongs to the Nisus and Scylla episode. I have selected the reference to the color of Nisus' lock of hair, purple in Ovid, but golden in Bonsignori and Alegre. Del Virgilio does not mention the color of Nisus' hair: "Sed rex illius ciuitatis scilicet Nisus habebat cirrum Capillorum de quo fatatum erat quod dum haberet non posset regnum amittere (f. $\left.31 v^{0}\right) .{ }^{66}$ It is also golden in

59 'Because Androgeous, son of Minos, king of Crete, was killed out of envy when he was in Athens [...]'.

60 'Androgeous, son of Minos, king of the Crete island, was killed out of envy by some students in Athens, since he used to learn more than his classmates did'.

61 'The king Minos decreed vengeance for the death of Androgeous, his son, killed in Athens when he was a student. He was preparing to wage war against this city'.

62 I thank Frank T. Coulson for allowing me to read his transcription of this passage from Vat. lat. 1598, f. 71rํ․

63 "Bright purple" (Lombardo 2010, 205, v. 10, "Nisus and Scylla”).

64 'Gold'.

65 'Gold'.

66 'But the king of the city, Nisus, had a bewitched lock of hair. While he had it, he could not lose his kingdom'. Milan, Biblioteca nazionale Braidense (Brera), AF.XIV.21, f. 31o․ I am deeply 
another Catalan text containing a rewrite of the myth, Parlament en casa de Berenguer Mercader ('Coloquium in Berenguer Mercader's Place'), edited by Martos (2001, 261). Set down by Joan Roís de Corella between 1456 and 1458, it was probably known to Alegre. In a footnote, Martos argues that, even if the Greek tradition, Ovid, the First and the Second Vatican Mythographers and the Ovidius moralizatus describe the lock of hair as purple, the Ovide moralise en prose already said it was golden. This link between certain medieval texts dealing with Ovid's Metamorphoses highlights the relevance of working on the connections among them, as Moncunill Martí $(2015,149)$ has suggested.

Nevertheless, Del Virgilio, Bonsignori and Alegre are singled out when taking into account more features from the same episode. While Ovid (VIII, v. 5) and Corella (Martos 2001, 263) state that Scylla cut her father's hair, Del Virgilio, ${ }^{67}$ Bonsignori (Ardissino 2001, 383) and Alegre (f. 65v의 $64 \mathrm{v}$ ㅇ]) refer to her cutting off his head. Later on, when the maiden appears in front of Minos, these three writers specify that she shows her father's head to the foreign king.

\section{EXAmple 10 (воок IX)}

The next example has been taken from Hercules' last speech, addressed to Jupiter (Ovid IX, vv. 176-204). In this passage, he lists a series of achievements he has accomplished. After recalling how he killed Diomedes and his horses, the hero proceeds with the strangling of the Nemean lion. However, Bonsignori and Alegre - unlike Del Virgilio (Ardissino 2001, 467) - follow with one deed that some manuscripts add in verse 197: "(h)is cacus (h)orrendum tiberino (in) litore monstrum” MonBF ${ }^{2 m} L^{3 m}$ (Tarrant 2004, IX, v. 197).68

- “io vensi Cacco [...]. Costui era ladro ed aveva una spelunga nel colle Tiberino” (Ardissino 2001, 436). ${ }^{69}$

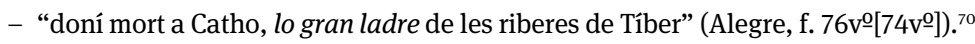

Once more, Alegre might have drawn on the Italian text, as the italicized detail is included neither in Del Virgilio's compilation nor in the manuscripts reporting Ovid's poem. This information could also originate with marginal commentaries on the poem. Ardissino (2001, 467) suggests Servius (In Aeneis, 8) as Bonsignori's

thankful to Beatrice Wyss and Gerlinde Huber-Rebenich for sharing this passage of Del Virgilio's text with me as well as the one in example 18.

67 Milan, Biblioteca nazionale Braidense (Brera), AF.XIV.21, f. 68vo․

68 'With [my arms I killed] Cacus, the terrible monster on the Tiber's banks'.

69 'I defeated Cacco [...]. He was a thief and he had a cave on the hill Tiberino'.

70 'I killed Catho, the great thief of the Tiber's banks'. 
source, although she does not acknowledge the lectio of the aforementioned manuscripts.

\section{EXAMPLE 11 (воOК X)}

- "cum tandem Cinyras, auidus cognoscere amantem / post tot concubitus, inlato lumine" (Tarrant 2004, X, 472s.). ${ }^{71}$

- "voluit eam videre et fecit portari lumen" (Del Virgilio, 101ro, Ardissino 2001, 506).72

- "essendo Cinnara in letto con la donna, volse vedere con cui elli giacea e sì chiamò uno suo servo e fece arricare lo lume" (Ardissino 2001, 492). ${ }^{73}$

- "Cinaras, desijós de conèxer la donzella ab qui tantes nits havia descansat, pensant que ya no tenguera vergonya, féu portar a un patge una atxa encesa” (Alegre, f. $88 \mathrm{v}$ 요 [86vo])..$^{74}$

Aside from Alegre's addition (underlined), the Catalan translator introduces a new character, the servant who brings the torch, through the Italian text, which, in turn, had been influenced by Del Virgilio's reading of the Latin poem.

\section{EXAMPLE 12 (воOК XI)}

At the beginning of book 11, Ovid narrates the death of Orpheus. Following verses 23-27, Bonsignori recasts the following lines as a defense of the poet by the animals surrounding him. This alteration is explained by the confusion arising from Ovid's use of pronouns in this passage, which is reflected in Del Virgilio's text (Ardissino 2001, 536). Alegre follows the Italian text and reproduces the resistance of the beasts; however, the Catalan text still shows confusion regarding the genre of the subjects - "ocells"/birds (masculine), "feres"/beasts (feminine) and "dones"/women - in the previous lines.

- "[...] et fronde uirentes / coniciunt thyrsos non haec in munera factos. / hae glaebas, illae dereptos arbore ramos, / pars torquent silices” (Tarrant 2001, XI, vv. 27-30)..$^{75}$

- "alcuno de quelli ucelli e fiere per ira e per compassione de Orfeo percoteano le tirse, cioè quelle armi con le quali le donne aveano ferito Orfeo, alcuna percoteano le pietre ed

71 "Finally, after so many beddings, Cinyras, / Eager to know what his mistress looked like, / Brought in a lamp" (Lombardo 2010, 282, vv. 542-544, "Myrrha and Cinryas").

72 'He wanted to see, so he asked for light'.

73 'Being Cinryas in bed with the woman, he wanted to see with whom he slept, so he called one of his servants and he asked him for a lamp'.

74 'Cinryas, eager to see the maiden with whom he had lain down many nights, convinced that she would no longer be embarassed, asked a page to bring a burning torch'.

75 "Hurling / Their green-leaved thyrsi, made not for this use. / Some threw clods of earth, some branches ripped from trees, / Some stones" (Lombardo 2010, 295, vv. 27-30, "The Death of Orpheus”). 
alcuna li rami de l'arbori ed alcune le zape della terra, le quali le donne avevano gettato ad Orfeo" (Ardissino 2001, 510). ${ }^{76}$

- "[Los aucells e tota la host de feres] Y, mostrant ab lur gest quant del seu dan restaven anujats, uns mordían ab rabioses dents l'escorsa de les astes qui l'havían nafrat; altres ab força de lurs peus lançaven luny les pedres y los aucells ab bechs rompían las glebas de la terra" (Alegre, f. 92ro[90ro]). ${ }^{77}$

\section{EXAMPLE 13}

In the same book, at the beginning of the Ceyx and Alcyone episode, Ceyx decides to consult an oracle "ad Clarium" (Tarrant 2004, XI, v. 413), that is to say, 'in Claros', as the journey to Delphi was unsafe (Lombardo 2010, 309, v. 486). The destination is reported in Del Virgilio (111r) as: "Elotium insulam" (Ardissino 2001, 538) and, as “all'isola de Dazio” (Ardissino 2001, 526) in all of the manuscripts that transmit the Italian text. However, the first edition of Bonsignori's work reports "Delfos", instead, although it shows an evident contradiction with the stated fact that Delphi was at war (Ardissino 2001, 538). Similarly, the Catalan text contains a lectio close to the editio princeps: "a la isla de Delon". Alegre goes on with the following words: "per consultar Apol-lo de sos fets, perquè lo camí per lo temple de Delfon empatxava Forbas ab cruel guerra" (Alegre, f. $96 \mathrm{v}$ [0 $94 \mathrm{v}$ 의). ${ }^{78}$ There is only a small modification in the spelling of the name of the place (Delon/Delfon) that may conceal the contradiction.

Paradoxically, the Italian text was printed later than the Catalan translation. Nonetheless, nothing is known about the manuscript used in preparation for the former incunabula, as Ardissino (2001, xli-xlii) explains. According to the scholar, this text was the result of the intervention of a learned person and, even if she takes it into account when building the apparatus, its critical edition has yet to be undertaken.

76 'Some of the birds and animals beat their spears, that is to say, the weapons that had been used by those women to wound Orpheus. Some of them hit the stones; others, the branches of the trees and other ones, the clods of earth they had thrown at Orpheus'.

77 'The animals showed through their actions they were upset due to the harm inflicted on Orpheus. Some of them bit with enraged teeth the surface of the spears that had wounded him; others, with their feet's strength, cast those stones away and the birds' peaks broke clods of earth'. 78 'In order to ask Apollo about his future, since the journey to Delphi was obstructed because of Phorbas' war'. 


\section{EXAMPLE 14 (воOK XII)}

- "fuluis / uidit auem pennis" (Tarrant 2004, XII, vv. 524-525).79

- "Conversus fuit in volucrem" (Del Virgilio, 123r, Ardissino 2001, 565). ${ }^{80}$

- "Tercia est de Ceneo mutato de femina in masculum, postea in avem fenicem" (Del Virgilio, Allegorie, Ghisalberti 1933, 93). ${ }^{81}$

- "Moffeo, dicea ch'elli s'era convertito in fenice" (Ardissino 2001, 556). ${ }^{82}$

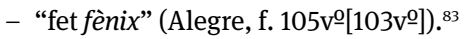

This excerpt deals with the transformation of Caenus into a bird within the episode of the battle of the Lapiths against the centaurs at the end of book 12 . Here, Ovid does not mention the kind of bird into which Caenus was transformed, whereas Bonsignori and Alegre identify it as a phoenix. In fact, Ardissino (2001, 565) suggests that the Italian compiler might have drawn on Del Virgilio's Allegorie, in which he affirms (both in verse and in prose) that Caenus was transformed into a phoenix - although this information was not in his Expositio.

\section{EXAMPLE 15 (воOК XIII)}

- "quod toto caerulus ore” (Tarrant 2004, XIII, v. 895). ${ }^{84}$

- "ed avea el capo aurato" (Ardissino 2001, 606). ${ }^{85}$

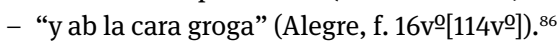

The Italian and the Catalan text report the same lectio.

\section{EXAMPLE 16 (воOK XIV)}

Alegre does not attribute Cassandra's rape to Ajax, but, rather, to Ulysses, whom the Catalan translator disparages in the episode regarding the contest between Ajax and Ulysses for Achilles' arms in the previous book. Therefore, where Ovid reads:

79 "For he saw a bird with golden wings rise up" (Lombardo 2010, 342, v. 602, "The Battle of the Lapiths and the Centaurs").

80 'It was transformed into a bird'.

81 'The third allegory refers to Caenus transformed from a woman into a man and, later on, into $a$ phoenix'.

82 'Mopsus said that he had been transformed into a phoenix'.

83 'Transformed into a phoenix'.

84 “And his face was deep blue” (Lombardo 2010, 376, v. 1067, "Polyphemus' Song to Galatea”).

85 'And his head was gold-colored'.

86 'And his face was yellow'. 
- "Naryciusque heros, a Virgine uirgine rapta / quam meruit poenam solus digessit in omnes” (Tarrant 2004, XIV, vv. 468-469). ${ }^{87}$

\section{the Catalan text states:}

- "havent Ulixes presa la verge del temple de la verge, passant la pena deguda a la culpa d'ell sol en tots nosaltres" (Alegre, f. $122 \mathrm{v}\left[120 \mathrm{v}\right.$ 의). ${ }^{88}$

In fact, Alegre would have conflated the rape of Cassandra by Ajax, which caused Minerva's rage, with Ulysses' theft of the palladium, Minerva's statue, from her temple. This story is narrated in book XIII. Bonsignori's text contains both references - the statue and Cassandra - and it is useful to clarify the misunderstanding:

- “Aiaxileus, el quale era preso de l'amore de Casandra vergene, la qual guardava lo tempio della dea Pallas, Aiaxileus andò in lo ditto tempio e sì tolse la ditta imagine, non ostante che si dica che fosse Ulisse. Ma ciò non fu vero" (Ardissino 2001, 639). ${ }^{89}$

\section{EXAMPLE 17 (воOK Xv)}

- "umbrasque silentum / errauisse ferunt" (Tarrant 2004, XV, vv. 797-798).90

- "l'ombre de l'inferno andavano per la città" (Ardissino 2001, 704). ${ }^{91}$

- "les ànimes de l’infern exiren passejant per la nostra ciutat” (Alegre, f. 133ro[132ro]). ${ }^{92}$

Bonsignori and Alegre add a reference to Christianity in their texts. The structure of the sentence is the same one in the Italian and the Catalan translations.

In conclusion, the seventeen cases discussed in this article prove the dependence of the Catalan translation on the Italian compilation. Furthermore, examples 1, 2, 3, 5, 7, 8 and 10 confirm that, regardless of Del Virgilio's works, Alegre must have known Bonsignori's text.

87 "After Minerva, / A virgin goddess in defense of a ravaged virgin, / Had punished us all for Ajax's rape of Cassandra” (Lombardo 2010, 402, vv. 543-545, “Acmon”).

88 'After Ulysses had taken the virgin from the virgin's temple, we were all punished because of him'.

89 'Ajax was in love with the virgin Cassandra, who was a priestess in Pallas' temple. Ajax went to the temple and took the above-mentioned image, although this action has been attributed to Ulysses. Such a statement is not true'.

90 "Silent shades / Walked abroad" (Lombardo 2010, 442, vv. 888-889, "The Deification of Cesar”).

91 'And the shades from hell walked the city'.

92 'And the souls from hell went out strolling through our city'. 


\section{Parallelisms Between Del Virgilio and Alegre}

In the following two examples, I will argue that Alegre might have also drawn on Del Virgilio's Expositio and Allegorie, although I have yet to find more cases that support this hypothesis.

\section{EXAMPLE 18}

- "Carmina Laiades non intellecta priorum / soluerat ingeniis, et praecipitata iacebat / immemor ambagum uates obscura suarum" (Tarrant 2004, VII, vv. 759-761). ${ }^{93}$

- "madonna Temis era adorata da quelli de Teba, tanto che lla dea dava a lloro responso, e queste resposte erano tanto scure che lli tebani non l'intendeano e per questo sì la spregiavano ed andavano alle Driades, le quali aveano resposte e più chiare" (Ardissino 2001, 368).94

- "Los hòmens de Tebas, primer no entenent les respostes duptoses de la deessa Temis, dexaren los altars de aquella sens dons ni sacrificis y, voltats a les nayes, cobraven d'ellas

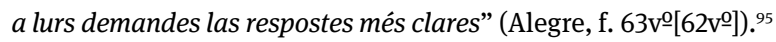

In this passage, the vernacular texts introduce an addition in relation to the Latin poem - italicized in both texts-; however, there is a difference between the two works: where Bonsignori mentions the Dryads, the Catalan translation refers to the Nayads. In fact, Ardissino $(2001,378)$ clarifies that, even if the Italian compiler is following Del Virgilio, the latter discusses the Nayads $(66 \mathrm{v}-\mathbf{0})$. Therefore, Alegre's lectio is closer to Del Virgilio: "Thebani eam spernebant et ibant ad Naiades que dabant meliora responsa et clariora". ${ }^{96}$

\section{EXAMPLE 19}

The next example has been taken from the allegorical interpretations that these medieval authors composed regarding Ovid's poem. Alegre's “al-legories e morals exposicions" draw on Boccaccio’s Genealogia deorum gentilium as its main source, as the Catalan author acknowledges in his work (Badia 1986). Nevertheless, I have

93 "After Oedipus had solved the riddle of the Sphinx / She plunged to her death, and the dark prophetess lay / Forgetful of her misterious sayings" (Lombardo 2010, 199, vv. 840-842, "Procris and Cefalus").

94 'Themis was adored so much by the Thebans that the goddess answered them. But her answers were obscure; therefore, they rejected them and turned to the Dryads, whose answers were clearer'.

95 'Initially, the Thebans did not understand the goddess Themis' obscure answers. They left her altars without gifts or sacrifices and they turned to the Nayads to receive clearer answers'.

96 'The Thebans despised her and turned to the Nayads, who gave them better and clearer answers'. Latin text transcribed from Milan, Biblioteca nazionale Braidense (Brera), AF.XIV.21, f. 31ํㅡ by Beatrice Wyss and Gerlinde Huber-Rebenich. The Ovide moralisé (Boer/Boer/Van't Sant 1936, VII, 3048) also refers to the naiads ('les nimphes d'iaue'). 
chosen an episode that Boccaccio does not report in order to illustrate how he turns to Del Virgilio and Bonsignori also in his commentaries. The example belongs to Pyramus and Thisbe's story (book IV):

- "Quarta transmutatio est de moris que de albis versa sunt in nigra. Nam verum est quod morus prius producit mora alba, deinde cum sunt matura efficiuntur nigra. Moraliter ergo per hoc possumus notare quod in amore qui est dulcis in principio aliquando mors latet, quia ad ipsum sepe consequitur mors sicut consecutum fuit in istos duobus” (Del Virgilio, Allegorie 55, Ghisalberti 1933). ${ }^{97}$

- "Così quando l'uomo e la donna sono in puerizia ed in castità sono bianchi, senza macula; poi che sono oppressi da libidine deventano vermigli per lu fuoco della lussuria. [...] Ed ancora spesse volte per carnale amore s'acquista la morte, sì come avenne a Pirramo e a Tisbe" (Ardissino 2001, 219). ${ }^{98}$

- "[...] Se pot en açò moral seny aplicar, per la blancor de les móres entenent lo començ de l'amor, blanch e plasent [...]. Però com se madura, ço és, acabada la força del desijar, passant lo desig en fruïció, la que.s mostrave blanque pren la color vermella [...]. Y sovint aporte a la mort los qui amen, com féu als dos de Babilònia” (Alegre, f. 174r으무이무). ${ }^{99}$

Although not reproduced here, Bonsignori and Alegre begin their interpretation of the myth by commenting on its historical sense. Afterwards, the three texts explain its moral meaning: the vernacular authors condemn lust, while Del Virgilio does not mention it. Additionally, the Catalan text also shares a common feature with the Latin compilation that is not in Bonsignori - highlighted in italics - the description of the beginning of love as sweet or pleasant. ${ }^{100}$ The Catalan translator here seems to combine both lectiones.

97 'The fourth transformation deals with blackberries, which go from white to black. In fact, it is true that mulberries produce white fruit at first; then, when they ripen, they blacken. Therefore, the moral of the story is that, although sweet at first, love may hide death, as it often results in death, as befell this pair'.

98 'Therefore, men and women are white and untainted while they are chaste infants. But, when they feel the urge of desire, they become red because of the flame of lust [...]. Moreover, carnal desire often causes death, as it was the case with Pyramus and Thisbe'.

99 'The moral of the story shall also be interpreted. The blackberries' whiteness symbolizes the beginning of love, white and pleasant [...]. But when they ripen - that is to say, when passive desire turns into real pleasure/lust, - what was once white reddens [...]. Moreover, it often causes death to lovers, as was the case with the pair from Babylon'.

100 The information Alegre might have taken from Del Virgilio is both in verse and in prose in the Allegorie. 


\section{Conclusions}

Transformacions is the work of a learned author who assembles and selects different sources to fulfill his goal of offering a vernacular translation of Ovid's Metamorphoses that surpassed the ones he claims to know. As stated in his epilogue, his objective is to present a faithful translation of the Latin poem which preserves the style of Ovid's work in prose (its "fragrant flowers", Duran/Solervicens 1996, 40). Regardless of whether he accomplishes the latter or not, he adopts a clear model for his prose that he also uses in his sentimental romances: the learned style called prosa d'art, which is far removed from Del Virgilio's or Bonsignori's colloquial style. Alegre's choices show the importance he gives to the embellishment of the text. He also avoids digressions from the Metamorphoses.

Nevertheless, as examples 2, 8 and 14 showed, the Catalan translator is aware of his audience and cares about the intelligibility of his text. This is why he introduces brief glosses and he specifies the nature of some transformations, such as those of the phoenix and the bat. In fact, this case reveals how Alegre turns to Bonsignori as an aid to translate an etymological reference that, otherwise, would be lost in the vernaculars. The influence of this work also places the Catalan text in relation to the medieval tradition, in the sense that Moncunill Martí (2015) pointed out, as we saw in example 9. In contrast, Alegre's theoretical framework, expressed in the paratext and reflected in his work, links his ideas regarding literature and translation with Cristoforo Landino (Alcina 1998, 41) and Leonardo Bruni (Bescós Prat 2011).

In addition, Alegre employs Bonsignori to solve a confusing passage in example 12. In this article, I have proved that he is certainly consistent in the use of the Italian compilation as an aid for his translation throughout the fifteen books and also in his allegories. This claim may seem a contradiction with the fact that Alegre criticizes the dependence on previous translations into vernacular from Del Virgilio and Bonsignori. But, unlike in his own version of Bruni's De primo bello punico, here, his main source is not an Italian text, but Ovid's poem. ${ }^{101}$ Furthermore, his statement against this practice in the epilogue already shows his knowledge of the Italian tradition, which is also evident in the second part of his work (Boccaccio) and in his sentimental romances (Petrarch). Nevertheless, Alegre chooses to disclose the latter two sources as auctoritates; however, he does not acknowledge Del Virgilio's influence and, intentionally or not, he does not

101 In fact, Alegre was convinced that Bruni had penned the Italian version of De primo bello punico (Badia 1986, 103). 
mention Bonsignori's name. In fact, this information would not have been useful for his epilogue's defense of the need for a new translation of the Metamorphoses true to Ovid.

Regardless, Alegre's epilogue is the only document that informs us of these previous Catalan and Spanish translations of the Metamorphoses and their source. This suggests that Bonsignori was well-known in the Crown of Aragon in the second half of the fifteenth century - at least, in the milieu of the prince Carlos de Viana. However, the transmission of this work in the Crown of Aragon warrants further study, together with the circulation of Del Virgilio's Expositio and Allegorie. The form in which Alegre knew Bonsignori's compilation may have been a complete text and, according to his own accounts, the Catalan translator does not seem to know Simintendi's work, which was closely linked to Bonsignori in the Italian circulation of his text. To be sure, it should be compared with the Catalan translation in full. ${ }^{102}$

\section{Bibliography}

Alcina, Juan F., El poeta como Dios: la poética de Landino en España (de Francesc Alegre a Alfonso de Carvallo), Salina 12 (1998), 40-49.

Alegre, Francesc, Transformacions, Barcelona, Biblioteca de Catalunya (Bon 10-VI-29), printed by Pere Miquel, 1494.

Ardissino, Erminia (ed.), Giovanni Bonsignori, Ovidio Metamorphoseos Vulgare, Bologna, Commissione per i testi di lingua, 2001.

Badia, Lola, Per la presència d'Ovidi a l'Edat Mitjana, amb notes sobre les traduccions de les "Heroides" i de les "Metamorfosis" al vulgar, in: Studia in honorem prof. M. de Riquer, vol. 1, Barcelona, Quaderns Crema, 1986, 39-71.

Bellido, José A., et al., Ovid's Metamorphoses. Research Project, updated on: 10.10.2014, <http://www.uhu.es/proyectovidio/ing/index.html> [last access: 27.04.2016].

Bescós Prat, Pere, Humanisme i traducció catalana durant la segona meitat del segle XV: Ferran Valentí, Arnau d'Alfarràs, Francesc Alegre i Aleix de Barcelona, MA's thesis, Barcelona, Universitat Pompeu Fabra, 2007, <https://repositori.upf.edu/bitstream/handle/10230/ 1268/PereBescos.pdf?sequence=1> [last access: 27.04 .2016 ].

102 This article has received the support of the Secretary for Universities and Research of the Ministry of Economy and Knowledge of the Government of Catalonia and the Department of the Classics at Harvard University. Moreover, I would like to thank Josep Pujol for the critical reading of this article and Richard J. Tarrant and Lola Badia for their help. I am also grateful to Martí Duran and Marta Segarrés, who collaborated on this project and to Beatrice Wyss, Gerlinde HuberRebenich, Elisa Guadagnini, Valeria Cotza, Luís Rivero García, Frank T. Coulson, Lluís Cabré, Ana Pairet, Erminia Ardissino, Gabriella Albanese and Fulvio Delle Donne for their suggestions. Finally, I appreciate the review of the text by the FAS Postdoc Editors Association at Harvard. 
Bescós Prat, Pere, Francesc Alegre: La primera guerra púnica, 1472. Estudi i edició crítica, Dissertation, Barcelona, Universitat Pompeu Fabra, 2011, <http://www.tdx.cat/handle/ 10803/31878> [last access: 27.04.2016].

Bescós Prat, Pere, Comentari i formació literària en Francesc Alegre: Ovidi i Bernardo llicino, Llengua \& Literatura 24 (2014), 33-53.

Boer, Cornelis de (ed.), Ovide moralisé, vol. 1, Amsterdam, Müller, 1915.

Boer, Cornelis de/Boer, Martina G. de/Van't Sant, Jeannette Th. M. (edd.), Ovide moralisé, vol. 3, Amsterdam, Müller, 1936.

Cabré, Lluís/Ferrer, Montserrat (edd.), Cens de traduccions al Català Medieval fins a 1500). “Ovidi. 'Transformacions'. Francesc Alegre" (TCM 92.3.1) and “Francesc Galceran de Pinós" (TCMP 10.1.1), updated on: 13.12.2011, <http://www.translatdb.narpan.net/ca/cercador. html> [last access: 27.04.2016].

Cifuentes, Lluís, La ciència en català a l'Edat Mitjana i el Renaixement, Barcelona, Universitat de Barcelona/Universitat de les Illes Balears, 2006.

Clark, James G./Coulson, Frank T./McKinley, Kathryn L. (edd.), Ovid in the Middle Ages, Cambridge, Cambridge University Press, 2011.

Copeland, Rita, Rhetoric, Hermeneutics and Translation in the Middle Ages, Cambridge, Cambridge University Press, 1991.

Duran, Eulàlia/Solervicens, Josep, Renaixement a la carta, Barcelona, Universitat de Barcelona and Eumo, 1996.

Ferretti, Matteo, Boccaccio, Paolo da Perugia e i commentari ovidiani di Giovanni del Virgilio, Studi sul Boccaccio 35 (2007), 85-110.

Ghisalberti, Fausto (ed.), Giovanni del Virgilio, espositore delle Metamorfosi, Firenze, Olschki, 1933.

Guadagnini, Elisa, Ovidio Metamorphoseos Vulgare [updated on: 11.02.2016], in: ead./Vaccaro, Giulio (edd.), Corpus del Dizionario dei Volgarizzamenti (DiVo), <http://tlion.sns.it/divo/ index.php?type $=$ db\&lang=it $>$ [last access: 27.04 .2016$]$.

Guasti, Ranieri (ed.), I primi V libri delle Metamorfosi d'Ovidio volgarizzate da Ser Arrigo Simintendi da Prato, Prato, Guasti, 1846 (On-line: <https://babel.hathitrust.org/cgi/pt? id=uc1.a0000219998; view=1up;seq=6> [last access: 27.04 .2016$]$ ).

Guthmüller, Bodo, Mito, poesía, arte. Saggi sulla tradizione ovidiana nel rinascimento, Roma, Bulzoni, 1997.

Hernando i Delgado, Josep, Del llibre manuscrit al llibre imprès. La confecció del llibre a Barcelona durant el segle XV. Documentació notarial, Arxiu de textos catalans antics 21 (2002), 257-603.

Lombardo, Stanley (ed.), Ovid, Metamorphoses, Indianapolis, Hackett, 2010.

Marfany, Marta, La traducción del Infierno de Fernández de Villegas. La huella de la tradición poética castellana y de los comentarios a la Commedia de Dante, Anuario de Estudios Medievales 45:1 (2015), 450-471.

Martí, Sadurní, El Cançoner del Marquès de Barberà (S1-BM1). (Descripció codicològica), Boletín Bibliográfico de la Asociación Hispánica de Literatura Medieval 11 (1997), 463-502.

Martos, Josep Lluís (ed.), Les proses mitològiques de Joan Roís de Corella, Barcelona, Publicacions de l'Abadia de Montserrat, 2011.

Moncunill Martí, Noemi, Las Metamorfosis de Ovidio traducidas por Francesc Alegre (1494): algunas observaciones sobre la problemática de las fuentes, in: Muñoz García de Iturrospe, María Teresa/Carrasco Reija, Leticia (edd.), Miscellania Latina, Madrid, Sociedad de Estudios Latinos, Universidad Complutense de Madrid, 2015, 145-151. 
Pujol, Josep, Expondre, traslladar i reescriure clàssics llatins en la literatura catalana del segle XV, Quaderns: revista de traducció 7 (2002), 9-32.

Pujol, Josep, El ámbito de la cultura catalana, in: Lafarga, Francisco/Pegenaute, Luís (edd.), Historia de la traducción en España, Salamanca, Ambos Mundos, 2004, 623-719.

Riera i Sans, Jaume, Catàleg d'obres en català traduïdes en castellà durant els segles XIV iXV, in: Ferrando, Antoni (ed.), Segon Congrés Internacional de la Llengua Catalana, vol. 8, Valencia, Institut Interuniversitari de Filologia Valenciana, 1989, 699-710.

Riquer, Martí de, Ovidi en l'antiga literatura catalana II, La Veu de Catalunya 11843 (31 May 1934), 8.

Rubió i Lluch, Antoni, Documents per a la història de la cultura catalana mig-eval, vol. 1, Barcelona, Institut d'Estudis Catalans, 1908-1921.

Tarrant, Richard J. (ed.), Ovid, Metamorphoses, Oxford, Oxford University Press, 2004.

Torró, Jaume, “Officium poetae est fingere": Francesc Alegre i la Faula de Neptuno i Dyana, in: Badia, Lola/Soler, Albert (edd.), Intel-lectuals i escriptors a la Baixa Edat Mitjana, Barcelona, Curial/Publicacions de l'Abadia de Montserrat, 1994, 221-242. 